\author{
B. Bekbolat ${ }^{1,2,3}{ }^{*}$, N. Tokmagambetov ${ }^{1,2,3}$ \\ ${ }^{1}$ Al-Farabi Kazakh National University, Almaty, Kazakhstan; \\ ${ }^{2}$ Institute of Mathematics and Mathematical Modeling, Almaty, Kazakhstan; \\ ${ }^{3}$ Department of Mathematics: Analysis, Logic and Discrete Mathematics, Ghent University, Belgium \\ (E-mail: bekbolat@math.kz,niyaz.tokmagambetov@gmail.com)
}

\title{
Well-posedness results for the wave equation generated by the Bessel operator
}

\begin{abstract}
In this paper, we consider the non-homogeneous wave equation generated by the Bessel operator. We prove the existence and uniqueness of the solution of the non-homogeneous wave equation generated by the Bessel operator. The representation of the solution is given. We obtained a priori estimates in Sobolev type space. This problem was firstly considered in the work of M. Assal [1] in the setting of Bessel-Kingman hypergroups. The technique used in [1] is based on the convolution theorem and related estimates. Here, we use a different approach. We study the problem from the point of the Sobolev spaces. Namely, the conventional Hankel transform and Parseval formula are widely applied by taking into account that between the Hankel transformation and the Bessel differential operator there is a commutation formula [2].
\end{abstract}

Keywords: Bessel operator, wave equation, Hankel transform, inverse Hankel transform, Sobolev type space.

\section{Introduction}

In this paper we consider the nonhomogeneous wave equation

$$
\frac{\partial^{2} u}{\partial t^{2}}-S_{\mu} u=f(x, t), \quad x \in R_{+}, \quad 0<t<T
$$

under the conditions

$$
u(x, 0)=u_{0}(x), u_{t}(x, 0)=u_{1}(x),
$$

where $T$ is fixed positive real number, generated by the Bessel operator

$$
S_{\mu} \triangleq \frac{d^{2}}{d x^{2}}+\frac{1-4 \mu^{2}}{4 x^{2}}
$$

where $\mu \geq-\frac{1}{2}$. The operator (1) is widely analysed in [2]. In the book [2], the author considered the Hankel transform in the countably multinormed space $\mathcal{H}$. Between the Hankel transform and (1) there is a commutation formula. The heat equation generated by (1) was studied in [3]. In [3], it was proved that the Cauchy problem has a unique solution $u(x, t)$ in the space $\left(U_{\mu, q^{\prime}, 1 /(b+d)}^{q^{\prime}, 1 /(a-d)}\right)^{\prime}, q^{\prime}=\left(2 p_{0}-1\right) /\left(2 p_{0}\right)$, for the interval $0 \leq t \leq T$, $T<\left(4 c p_{0}\right)^{-1}(d / 2)^{2 p_{0}}, d<a$. Where $\left(U_{\mu, q^{\prime}, 1 /(b+d)}^{q^{\prime}, 1 /(a-d)}\right)^{\prime}$ is dual for $U_{\mu, q^{\prime}, 1 /(b+d)}^{q^{\prime}, 1 /(a-d)}$. Here $U_{\mu, q^{\prime}, 1 /(b+d)}^{q^{\prime}, 1 /(a-d)}$ is a linear space (see [3]), where the topology over this space is generated by the norm

$$
\|f\|_{\delta \rho}=\sup _{s \in \mathbb{C}}\left|s^{-\mu-\frac{1}{2}} f(s)\right| \cdot \exp \left(q^{\prime}\left[\left(\frac{1}{b+d}-\delta\right) x\right]-q^{\prime}\left[\left(\frac{1}{a-d}+\rho\right) y\right]\right) .
$$

A generalized Bessel operator is given by the following expression

$$
\frac{d^{2}}{d x^{2}}+\frac{2 \mu+1}{x} \frac{d}{d x}
$$

In [1] the author studied the operator (2) in the setting of Bessel-Kingman hypergroups and as an application studied the homogeneous wave equation. In the paper [1] it is studied radial solutions of the Cauchy problem for the wave equations in the multidimensional unit ball $B^{d}, d \geq 1$. For more information about the analysis associated with the generalized Bessel operator, we refer to [4-10].

\footnotetext{
${ }^{*}$ Corresponding author.

E-mail: bekbolat@math.kz
} 


\section{The test function space}

The space $\mathcal{H}_{\mu}$ is defined for each $\mu \in \mathbb{R}$ as follows (see [2]):

Definition 1. $\mathcal{H}_{\mu}$ is a space of complex-valued, smooth functions and for each pair of $m, k \in \mathbb{Z}_{+}$with the seminorms

$$
\gamma_{m, k}^{\mu}(f) \triangleq \sup _{0<x<\infty}\left|x^{m}\left(x^{-1} D\right)^{k}\left(x^{-\mu-\frac{1}{2}} f(x)\right)\right|<\infty .
$$

Lemma 1. $\mathcal{H}_{\mu}$ is complete. Thus, it is a Fréchet space.

We denote by $\mathcal{H}_{\mu}^{\prime}$ the dual of $\mathcal{H}_{\mu}$. $\mathcal{H}_{\mu}^{\prime}$ is also complete.

We introduce following linear operators:

$$
\begin{gathered}
N_{\mu} f(x) \triangleq x^{\mu+\frac{1}{2}} D x^{-\mu-\frac{1}{2}} f(x), \\
M_{\mu} f(x) \triangleq x^{-\mu-\frac{1}{2}} D x^{\mu+\frac{1}{2}} f(x), \\
N_{\mu}^{-1} f(x) \triangleq x^{\mu+\frac{1}{2}} \int_{\infty}^{x} t^{-\mu-\frac{1}{2}} f(t) d t .
\end{gathered}
$$

Now, we can rewrite (1) as follows

$$
S_{\mu}=M_{\mu} N_{\mu}=\frac{d^{2}}{d x^{2}}+\frac{1-4 \mu^{2}}{4 x^{2}} .
$$

$S_{\mu}$ is a continuous linear mapping as

$$
S_{\mu}: \mathcal{H}_{\mu} \rightarrow \mathcal{H}_{\mu} .
$$

\section{The Hankel transform and its inverse}

If $\mu \geq-\frac{1}{2}$, for every $\phi \in \mathcal{H}_{\mu}$ we can define the conventional Hankel transform

$$
\Phi(y)=\left(h_{\mu} \phi\right)(y)=\int_{0}^{\infty} \sqrt{x y} J_{\mu}(x y) \phi(x) d x, \quad 0<y<\infty .
$$

Here, the kernel $\sqrt{x y} J_{\mu}(x y)$ is an eigenfunctions of the operator $S_{\mu}(1)$.

Lemma 2. ([2]) Assume that $\mu \geq-\frac{1}{2}$ and $f \in \mathcal{H}_{\mu}$. Then

$$
h_{\mu}\left(S_{\mu} f\right)=-y^{2} h_{\mu} f .
$$

Theorem 1. ([11]) Let $f \in L^{1}$. If $f$ is a bounded variation in a neighborhood of the point $x=x_{0}$, if $\mu \geq-\frac{1}{2}$, and if $F(y)$ is defined by (3), then

$$
\frac{1}{2}\left[f\left(x_{0}\right)+f\left(x_{0}-0\right)\right]=h_{\mu}^{-1} F=\int_{0}^{\infty} F(y) \sqrt{x_{0} y} J_{\mu}\left(x_{0} y\right) d y .
$$

Theorem 2. ([2]) The Hankel transformation $h_{\mu}$ is an automorphism on $\mathcal{H}_{\mu}$, for $\mu \geq-\frac{1}{2}$.

Theorem 3. ([2]) Let $\mu \geq-\frac{1}{2}$. If $f(x)$ and $G(y)$ are in $L^{1}(0, \infty)$ then

$$
\int_{0}^{\infty} f(x)\left(h_{\mu}^{-1} G\right)(x) d x=\int_{0}^{\infty} F(y) G(y) d y .
$$

Definition 2. ([12]) For $s, \mu \in \mathbb{R}$ and $1 \leq p<\infty$ the Sobolev type space $G_{\mu}^{s, p}$ is the set of all tempered distributions $u \in \mathcal{H}^{\prime}$ such that $U$ is locally integrable function over $I:=(0, \infty)$ and

$$
\|u\|_{G_{\mu}^{s, p}}^{p}:=\int_{0}^{\infty}\left(1+y^{2}\right)^{s p}|U(y)|^{p} d y<\infty .
$$

In view of the Parseval formula

$$
\|u\|_{2}^{2}=\|U\|_{2}^{2}, \quad \mu \geq-\frac{1}{2}
$$


it follows that

$$
G_{\mu}^{0,2}(I)=L^{2}(I)
$$

Theorem 4. ([12]) The Sobolev type space $G_{\mu}^{s, p}, 1 \leq p<\infty$, is complete.

Theorem 5. ([12]) $\mathcal{H}_{\mu}$ is dense in $G_{\mu}^{s, p}, 1 \leq p<\infty, \forall s \in \mathbb{R}$.

\section{Wave equation generated by the Bessel operator}

In this section, we consider the Cauchy problem for the nonhomogeneous wave equation generated by the Bessel operator on the $Q_{T}:=\left\{(t, x): t \in[0, T], x \in \mathbb{R}_{+}\right\}$. Our aim to prove that the Problem 1 has a unique solution in the space $C^{2}\left([0, T], L^{2}(I)\right) \cap C\left([0, T], G_{\mu}^{1,2}(I)\right)$.

Problem 1. Let $T$ be a fixed positive number. We aim to find a function $u=u(t, x)$ satisfying the nonhomogeneous wave equation

$$
u_{t t}(t, x)-S_{\mu} u(t, x)=f(t, x), \quad(t, x) \in Q_{T}
$$

under the conditions

$$
\begin{gathered}
u(0, x)=u_{0}(x), \\
u_{t}(0, x)=u_{1}(x) .
\end{gathered}
$$

The Problem 1 has solution in the space $C^{2}\left([0, T], L^{2}(I)\right) \cap C\left([0, T], G_{\mu}^{1,2}(I)\right)$ and as a result we obtain following theorem:

Theorem 6. Let $\mu \geq-1 / 2$ and assume that $f \in C\left([0, T], G_{\mu}^{1,2}(I)\right)$ and $u_{0}, u_{1} \in G_{\mu}^{1,2}(I)$. Then the Problem 1 has a unique solution $u$ and it can be represented by the expression

$$
\begin{gathered}
u(t, x)=\int_{0}^{\infty} \sqrt{x y} J_{\mu}(x y) \int_{0}^{t} F(\tau, y) \frac{\sin y(t-\tau)}{y} d \tau d y+ \\
\int_{0}^{\infty} \sqrt{x y} J_{\mu}(x y) U_{1}(y) \frac{\sin (y t)}{y} d y+\int_{0}^{\infty} \sqrt{x y} J_{\mu}(x y) U_{0}(y) \cos (y t) d y
\end{gathered}
$$

where $F(\tau, y), U_{0}(y)$ and $U_{1}(y)$ are Hankel transforms of the functions $f(t, x), u_{0}(x)$ and $u_{1}(x)$, respectively.

Proof. By using the Hankel transform, we can show the uniqueness of the solution if the later exists. First, we prove the existence of the solution. After using the Hankel transform $h_{\mu}(3)$ and (4) for (7)-(9), we obtain

$$
\begin{gathered}
U_{t t}(t, y)+y^{2} U(t, y)=F(t, y), \quad y \in R_{+}, \\
U(0, y)=U_{0}(y), \quad y \in R_{+} \\
U_{t}(0, y)=U_{1}(y), \quad y \in R_{+} .
\end{gathered}
$$

Solution of the equation (10) is

$$
\begin{gathered}
U(t, y)=\left(\int_{0}^{t} \frac{F(\tau, y)}{y} \cos (y \tau) d \tau+A(y)\right) \sin (y t)+ \\
\left(-\int_{0}^{t} \frac{F(\tau, y)}{y} \sin (y \tau) d \tau+B(y)\right) \cos (y t) .
\end{gathered}
$$

By using initial conditions (11)-(12) for (13), we have

$$
U(t, y)=\int_{0}^{t} F(\tau, y) \frac{\sin y(t-\tau)}{y} d \tau+U_{1}(y) \frac{\sin (y t)}{y}+U_{0}(y) \cos (y t)
$$

After using the inverse Henkel transform $h_{\mu}^{-1}(5)$, we obtain that the solution of the problem (7)-(9) is given by

$$
\begin{gathered}
u(t, x)=\int_{0}^{\infty} \sqrt{x y} J_{\mu}(x y) \int_{0}^{t} F(\tau, y) \frac{\sin y(t-\tau)}{y} d \tau d y+ \\
\int_{0}^{\infty} \sqrt{x y} J_{\mu}(x y)\left(U_{1}(y) \frac{\sin (y t)}{y} d y+U_{0}(y) \cos (y t)\right) d y
\end{gathered}
$$

Mathematics series. № 1(101)/2021 
$F \lesssim G$ denotes $F \leq C G$ for some positive constant $C$ independent of $F$ and $G$.

Let $f \in C\left([0, T], G_{\mu}^{1,2}(I)\right)$ and $u_{0}, u_{1} \in G_{\mu}^{1,2}(I)$. By taking into account the definition of the space $G_{\mu}^{1,2}(I)$ (Definition 2), we obtain

$$
\begin{gathered}
\|u(t, \cdot)\|_{G_{\mu}^{1,2}}^{2}=\left\|\left(1+y^{2}\right) U(t, \cdot)\right\|_{2}^{2}=\int_{0}^{\infty}\left|\left(1+y^{2}\right) U(t, y)\right|^{2} d y \\
\lesssim \int_{0}^{\infty}\left|\left(1+y^{2}\right) \int_{0}^{t} F(\tau, y) \frac{\sin y(t-\tau)}{y} d \tau\right|^{2} d y+\int_{0}^{\infty}\left|\left(1+y^{2}\right) U_{1}(y) \frac{\sin (y t)}{y}\right|^{2} d y \\
+\int_{0}^{\infty}\left|\left(1+y^{2}\right) U_{0}(y) \cos (y t)\right|^{2} d y .
\end{gathered}
$$

Now, we are going to do some necessary calculations, as following

$$
\begin{gathered}
\int_{0}^{\infty}\left|\left(1+y^{2}\right) \int_{0}^{t} F(\tau, y) \frac{\sin y(t-\tau)}{y} d \tau\right|^{2} d y \\
=\int_{0}^{\infty}\left|\left(1+y^{2}\right) \int_{0}^{t} F(\tau, y) \frac{\sin y(t-\tau)}{y(t-\tau)} \cdot(t-\tau) d \tau\right|^{2} d y \lesssim \int_{0}^{\infty}\left(\left(1+y^{2}\right) \int_{0}^{t}|F(\tau, y)| d \tau\right)^{2} d y \\
\lesssim \int_{0}^{\infty}\left(1+y^{2}\right)^{2}\left(\int_{0}^{T}|F(t, y)| d t\right)^{2} d y \lesssim \int_{0}^{\infty} \int_{0}^{T}\left|\left(1+y^{2}\right) F(t, y)\right|^{2} d t d y=\int_{0}^{T}\|f(t, \cdot)\|_{G_{\mu}^{1,2}}^{2} d t
\end{gathered}
$$

here we used the Hölder's inequality and

$$
\begin{gathered}
\int_{0}^{\infty}\left|\left(1+y^{2}\right) U_{1}(y) \frac{\sin (y t)}{y}\right|^{2} d y=\int_{0}^{\infty}\left|\left(1+y^{2}\right) U_{1}(y) \frac{\sin (y t)}{y t} \cdot t\right|^{2} d y \\
\lesssim \int_{0}^{\infty}\left|\left(1+y^{2}\right) U_{1}(y)\right|^{2} d y=\left\|u_{1}\right\|_{G_{\mu}^{1,2}}^{2}
\end{gathered}
$$

Consequently, we have

$$
\|u(t, \cdot)\|_{G_{\mu}^{1,2}}^{2} \lesssim \int_{0}^{T}\|f(t, \cdot)\|_{G_{\mu}^{1,2}}^{2} d t+\left\|u_{1}\right\|_{G_{\mu}^{1,2}}^{2}+\left\|u_{0}\right\|_{G_{\mu}^{1,2}}^{2}
$$

From (14), we obtain

$$
\|u\|_{C\left([0, T], G_{\mu}^{1,2}(I)\right)}^{2}:=\max _{0<t<T}\|u(t, \cdot)\|_{G_{\mu}^{1,2}}^{2} \lesssim\|f\|_{C\left([0, T], G_{\mu}^{1,2}(I)\right)}^{2}+\left\|u_{1}\right\|_{G_{\mu}^{1,2}}^{2}+\left\|u_{0}\right\|_{G_{\mu}^{1,2}}^{2} .
$$

Now, for $u_{t t}$ we have

$$
\begin{gathered}
\left\|u_{t t}(t, \cdot)\right\|_{2}^{2}=\left\|U_{t t}(t, \cdot)\right\|_{2}^{2}=\int_{0}^{\infty}\left|U_{t t}(t, y)\right|^{2} d y=\int_{0}^{\infty}\left|F(t, y)-y^{2} U(t, y)\right|^{2} d y \\
\lesssim \int_{0}^{\infty}|F(t, y)|^{2} d y+\int_{0}^{\infty}\left|y^{2} U(t, y)\right|^{2} d y \lesssim\|F(t, \cdot)\|_{2}^{2}+\int_{0}^{\infty}\left|\left(1+y^{2}\right) U(t, y)\right|^{2} d y \\
=\|f(t, \cdot)\|_{2}^{2}+\|u(t, \cdot)\|_{G_{\mu}^{1,2}}^{2},
\end{gathered}
$$

by using the Parseval formula (6). Thus, we obtain

$$
\begin{gathered}
\|u\|_{C^{2}\left([0, T], L^{2}(I)\right)}^{2} \lesssim\|f\|_{C\left([0, T], L^{2}(I)\right)}^{2}+\|u\|_{C\left([0, T], G_{\mu}^{1,2}(I)\right)}^{2} \\
\lesssim\|f\|_{C\left([0, T], G_{\mu}^{1,2}(I)\right)}^{2}+\|u\|_{C\left([0, T], G_{\mu}^{1,2}(I)\right)}^{2} \lesssim\|f\|_{C\left([0, T], G_{\mu}^{1,2}(I)\right)}^{2}+\left\|u_{1}\right\|_{G_{\mu}^{1,2}}^{2}+\left\|u_{0}\right\|_{G_{\mu}^{1,2}}^{2} .
\end{gathered}
$$

The existence is proved.

Let us suppose that $u_{1}$ and $u_{2}$ are two solutions of Problem 1 . Then $u(t, x)=u_{1}(t, x)-u_{2}(t, x)$ is the solution of following problem:

$$
u_{t t}(t, x)-S_{\mu} u(t, x)=0, u(0, x)=0, u_{t}(0, x)=0 .
$$

Above problem has only trivial solution $u(t, x) \equiv 0$, showing the uniqueness of the solution of the Problem 1 . The uniqueness is proved. 


\title{
Acknowledgements
}

This research was funded by the Science Committee of the Ministry of Education and Science of the Republic of Kazakhstan (Grant No. AP08052028).

\section{References}

1 Assal, M. (2008). Generalized wave equations in the setting of Bessel-Kingman hypergroups. An International Journal for Theory and Applications, 11(3), 249-257.

2 Zemanian, A.H. (1968). Generalized Integral Transformations. Interscience, New York.

3 Pathak, R.S. (1985). On Hankel transformable spaces and a Cauchy problem. Can. J. Math., 37(1), 84-106.

4 Albeverio, S., Hryniv, R., \& Mykytyuk, Ya. (2007). Invers spectral problems for Bessel operators. J. differential Equations, 241, 130-159.

5 Ciaurri, Ó., \& Roncal L. (2014). The wave equation for the Bessel Laplacian. J. Math. Anal. Appl., 409, 263-274.

6 Dostanić, M.R. (2014). Spectral properties of the operator of Bessel potential type. J. Math. Anal. Appl., 419, 255-272.

7 Haimo, D.T. (1965). Integral equations associated with Hankel convolutions. Transactions of the American Mathematical Society, 116, 330-375.

8 Hirschman, I.I. (1960). Variation diminishing Hankel transforms. J. Analyse Math., 8, 307-336.

9 Masood, K., Messaoudi, S., \& Zaman, F.D. (2002). Initial inverse problem in heat equation with Bessel operator. International Journal of Heat and Mass Transfer, 45, 2959-2965.

10 Zaidman, S. (1991). Distributions and Pseudo-differential Operators. Copublished in the United States with John Wiley and Sons, Inc., New York.

11 Watson, G.N. (1922). A treatise on the theory of Bessel functions. Cambridge at the university press.

12 Pathak, R.S., \& Pandey, P.K. (1997). Sobolev type spaces associated with Bessel Operators. Journal of mathematical analysis and applications, 215, 95-111.

\section{Б. Бекболат, Н. Тоқмағамбетов}

\section{Бессель операторы арқылы туындаған толқын теңдеуі үшін тұрақтылық нәтижелері}

\begin{abstract}
Мақалада Бессель операторы арқылы туындаған біртекті емес толқын теңдеуі қарастырылған. Бессель операторы арқылы туындаған біртекті емес толқын теңдеуі шешімінің бар және жалғыздығы дәлелденген. Шешімнің түрі келтірілген. Соболев типтес кеңістікте априорлы бағалаулар алынған. Бұл есеп алғаш рет M. Assal [1] жұмысында Bessel-Kingman гипергруппасында қарастырылған. [1] жұмысында қолданылған әдіс үйірткі теоремасына және оған байланысты бағалауларға негізделген. Мақала авторлары бұл жұмыста басқа әдіс қолданған. Есеп Соболев кеңістігі көзқарасынан зерттелген. Атап айтқанда, Ханкель түрлендіруі және Парсеваль формуласы, Ханкель түрлендіруі және Бессель дифференциалдық операторы арасында коммутация формуласы бар екені ескеріле отырып [2], кеңінен қолданылады.
\end{abstract}

Kiлm сөздер: Бессель операторы, толқын теңдеуі, Ханкель түрлендіруі, кері Ханкель түрлендіруі, Соболев типтес кеңістік. 
Б. Бекболат, Н. Токмагамбетов

\section{Результаты корректности волнового уравнения, порожденного оператором Бесселя}

В статье рассмотрено неоднородное волновое уравнение, порожденное оператором Бесселя. Доказаны существование и единственность решения неоднородного волнового уравнения, порожденного оператором Бесселя. Приведено представление решения. Получены априорные оценки в пространстве соболевского типа. Эта проблема впервые была рассмотрена в работе M. Assal [1] в гипергруппе Bessel-Kingman. Метод, используемый в [1], основан на теореме свертки и связанных с ней оценках. Авторами статьи использован другой подход. Проблема изучена с точки зрения пространств Соболева. А именно преобразование Ханкеля и формула Парсеваля широко применяются с учетом того, что между преобразованием Ханкеля и дифференциальным оператором Бесселя существует коммутационная формула [2].

Ключевые слова: оператор Бесселя, волновое уравнение, преобразование Ханкеля, обратное преобразование Ханкеля, пространство соболевского типа. 